ROCZNIKI TEOLOGICZNE

Tom LXVIII, zeszyt $10-2021$

DOI: https://doi.org/10.18290/rt.216810.3

EWA KRZYŻAK-SZYMAŃSKA

\title{
KORZYSTANIE Z NOWYCH TECHNOLOGII CYFROWYCH PRZEZ DZIECI NIEPEŁNOSPRAWNE INTELEKTUALNIE W OPINII RODZICÓW
}

\author{
THE USE OF NEW DIGITAL TECHNOLOGIES BY INTELLECTUALLY \\ DISABLED CHILDREN IN THE OPINION OF THEIR PARENTS
}

\begin{abstract}
A b s t r a c t. The article presents the results of research conducted among parents of mildly intellectually disabled children. Their aim was to describe the knowledge of parents about the digital activities of their children and to characterise the activities of parents around children's use of new digital technologies. The research was carried out using the diagnostic survey method. 1295 people were involved. The research found statistically significant relationships between the frequency of using new media by parents and the frequency of using them by children. It was found that the parents first allowed their children to use computer games independently (the average age of initiation of use was 11 years), and then to use a mobile phone (the average age of initiation of use was 11 years and a half years). Then they introduced the child to the online world (the average age of initiation was 12). Additionally, statistically significant differences were found between working and non-working parents in terms of the principles of using new media applied at home. Almost 1/3 of the respondents reported Internet abuse by the child, every tenth parent pointed to the child's online contact with materials inadequate to his age, and every twentieth parent informed about the need to settle payments for applications or programs downloaded by the child from the Internet.
\end{abstract}

Keywords: children with intellectual disabilities; technological initiation; online risk; parents.

Dr Ewa KRZYŻAK-SZYMAŃSKA - Katedra Bezpieczeństwa Wewnętrznego, Akademia Wychowania Fizycznego im. Jerzego Kukuczki w Katowicach, 40-065 Katowice ul. Mikołowska 72A, adres do korespondencji: e-mail: e.krzyzak-szymanska@awf.katowice.pl; ORCID: https://orcid.org/0000-0002-7752-9266. 


\section{WPROWADZENIE}

Era technologii cyfrowych spowodowała, że korzystanie z internetu stało się integralną częścią codziennego życia młodego pokolenia. W dyskursie społecznym wskazuje się na powszechność korzystania przez dzieci i młodzież z sieci, w szczególności w zakresie zaspokajania ich codziennych potrzeb, spędzania czasu wolnego czy udziału w edukacji zdalnej ${ }^{1}$.

Badacze, poszukując informacji dotyczących sposobu korzystania z sieci przez cyfrowe pokolenie, skupiają swoją uwagę głównie na rodzajach aktywności online oraz szansach i ryzykach $\mathrm{z}$ nich wynikających ${ }^{2}$. Opisują oni świat technologii cyfrowych jako specyficzny ekologiczny techno-system ${ }^{3}$, w którym smartfon, internet mobilny, gry komputerowe stanowią integralna część środowiska rozwoju młodego człowieka. Taki stan powoduje, że pierwszym dostarczycielem, selekcjonerem czy kontrolerem cyfrowych „gadżetów” jest rodzic. To rodzice i opiekunowie odgrywają ważną rolę w kształtowaniu $\mathrm{u}$ dzieci właściwych relacji $\mathrm{z}$ mediami ${ }^{4}$. $\mathrm{Z}$ jednej strony zapewniając im możliwość zabawy, nauki i kontaktów społecznych w sieci, z drugiej ograniczając dostęp do negatywnych i szkodliwych treści online. Zagadnienie to jest tym bardziej ważne, jeśli dotyczy rodzin, w których wychowuja się dzieci niepełnosprawne intelektualnie wymagające szczególnego oddziaływania opiekuńczego, wychowawczego i edukacyjnego ${ }^{5}$.

W literaturze przedmiotu niepełnosprawność intelektualną zdefiniowano jako znaczne ograniczenie zarówno w obszarze funkcjonowania intelektualnego, jak i zachowań przystosowawczych, które identyfikuje się w umiejętno-

\footnotetext{
${ }^{1}$ Jacek Pyżalski, Aldona Zdrodowska, Łukasz Tomczyk i Katarzyna Abramczuk, Polskie badanie EU Kids Online 2018. Najważniejsze wyniki i wnioski (Poznań: Wydawnictwo Naukowe UAM, 2019).

${ }^{2}$ Ewa Krzyżak-Szymańska, Joanna Kowalkowska i Andrzej Szymański, Zagrożenia dzieci i młodzieży w sieci: cyberproblemy, diagnoza i profilaktyka: vademecum nauczyciela (Katowice: GWSH w Katowicach, 2016).

${ }^{3}$ Genevieve Marie Johnson and Korbla Puplumpu, "Internet Use during Childhood and the Ecological Techno-Subsystem," Canadian Journal of Learning and Technology 34(2008), https://doi.org/10.21432/T2CP4T.

${ }^{4}$ Andrzej Szymański i Ewa Krzyżak-Szymańska, ,Rola rodziców w zapobieganiu nadużywania przez dzieci nowych technologii cyfrowych", Serwis Informacyjny UZALEŻNIENIA 3(2018): 17-21; Karolina Komsta-Tokarzewska, Rodzina a ryzyko uzaleznienia od Internetu (Lublin: Wydawnictwo Polihymnia, 2020).

${ }^{5}$ Piotr Plichta, Socjalizacja i wychowanie dzieci i młodzieży z niepetnosprawnościa intelektualna w erze cyfrowej (Toruń: Wydawnictwo Adam Marszałek, 2017).
} 
ściach poznawczych, społecznych i praktycznych ${ }^{6}$. Natomiast niepełnosprawność intelektualną w stopniu lekkim scharakteryzowano w trzech obszarach:

1. Sfera pojęciowa. Określono, że u dzieci w wieku szkolnym i u dorosłych widoczne są różnice w stosunku do osób zdrowych w zakresie rozwoju umiejętności: czytania, pisania, arytmetyki, poprawności odczytywania wskazań zegara i rozpoznawania nominałów banknotów. W wieku dorosłym identyfikujemy także upośledzenie myślenia abstrakcyjnego, funkcji wykonawczych, np. strategii działania, planowania czy pamięci krótkotrwałej. Dodatkowo, w charakteryzowanej grupie osób występują problemy ze skutecznym wykorzystywaniem umiejętności szkolnych oraz usztywnione podejście do rozwiązywania problemów.

2. Sfera społeczna. Wskazano, że osoby z analizowanej grupy charakteryzuje niedojrzałość w zakresie interakcji społecznych, w szczególności w zakresie sygnałów wysyłanych przez rówieśników. Ponadto cechuje je trudność w kontrolowaniu emocji i podejmowaniu zachowań typowych dla wieku. Dodatkowo, występuje u nich ograniczone rozumienie ryzyka, które towarzyszy relacjom społecznym i niedojrzałość umiejętności oceny społecznej, co z kolei przekłada się na łatwowierność.

3. Sfera praktyczna. Opisano, że osoby niepełnosprawne intelektualnie o poziomie łagodnym mogą wymagać pomocy przy złożonych czynnościach codziennych oraz wsparcia przy czynnościach towarzyszących organizacji czasu wolnego lub rekreacji. Osoby dorosłe wymagaja pomocy w zakresie podejmowania decyzji z obszaru opieki zdrowotnej czy działań prawnych ${ }^{7}$.

Dotychczas w centrum zainteresowania badaczy były głównie zachowania online dzieci i młodzieży pełnosprawnej. Tylko nieliczne doniesienia skupiały się na niepełnosprawnych użytkownikach sieci $^{8}$. Na podstawie ich analizy ustalono, że korzystanie $\mathrm{z}$ nowych technologii cyfrowych nie odbiega w znaczny sposób

\footnotetext{
${ }^{6}$ Robert L. Schalock, Ruth Luckasson, and Marc J. Tassé, ,Intellectual Disability: Definition, Diagnosis, Classification, and Systems of Supports, 12th Edition" (AAIDD, 2021), https:// www.aaidd.org/publications/bookstore-home/product-listing/intellectual-disability-definition-diag nosis-classification-and-systems-of-supports-12th-edition.

${ }^{7}$ Piotr Gałecki, Maciej Pilecki, Joanna Rymaszewska, Agata Szulc, Sławomir Sidorowicz i Jacek Wciórka, Kryteria diagnostyczne zaburzeń psychicznych DSM-5, wydanie piąte (Wrocław: EDRA Urban i Partner, 2018).

${ }^{8}$ Sue Caton and Melanie Chapman, „The use of social media and people with intellectual disability: A systematic review and thematic analysis," Journal of Intellectual and Developmental Disability 41(2016): 125-39; Claude L. Normand i François Sallafranque-St-Louis, „Cybervictimization of Young People With an Intellectual or Developmental Disability: Risks Specific to Sexual Solicitation," Journal of Applied Research in Intellectual Disabilities 29(2016): 99-110.
} 
w grupie dzieci i młodzieży niepełnosprawnych i pełnosprawnych. Osoby niepełnosprawne używały technologii cyfrowych (w szczególności internetu) z powodów społecznych (takich jak randki lub spotkania z ludźmi) lub do celów rekreacyjnych (takich jak uczestnictwo w grach online). Środowisko sieci było też dla nich przestrzenią niwelowania samotności jak również możliwością unikania negatywnych uczuć ${ }^{9}$. W literaturze przedmiotu opisuje się jednostki niepełnosprawne intelektualnie jako użytkowników internetu, którzy charakteryzują się większą łatwowiernością, brakiem przewidywalności skutków zachowań ryzykownych w sieci czy niedostateczną ochroną swoich danych osobowych.

Dodatkowym elementem spojrzenia na korzystanie z sieci przez dzieci jest perspektywa rodzica - jego wiedzy na temat szans i zagrożeń cyberświata dla jego rozwoju ${ }^{10}$ oraz działań w przestrzeni edukacji medialnej. Badania potwierdzają, że zwykle rodzice nie wiedzą, co ich dzieci robią w internecie ${ }^{11}$. Ponadto ich wiedza technologiczna jest niższa niż ich dzieci ${ }^{12}$. Często nie mają oni też świadomości jak wprowadzać swoje dziecko w świat online i jakich reguł przestrzegać ${ }^{13}$.

Dlatego też przedmiotem badań stali się rodzice dzieci niepełnosprawnych intelektualnie w stopniu lekkim, a ich celem było opisanie użytkowania przez dzieci niepełnosprawne intelektualnie w stopniu lekkim nowych technologii cyfrowych w perspektywie ich rodziców.

\section{ZAŁOŻENIA METODOLOGICZNE I PROCEDURA BADANIA}

Prezentowane badania zostały zrealizowane wśród rodziców uczniów niepełnosprawnych intelektualnie w stopniu lekkim uczących się w klasach siód-

\footnotetext{
${ }^{9}$ Cristina Jenaro, Noelia Flores, Maribel Cruz, Ma Carmen Pérez, Vanessa Vega, and Victor Torres, „Internet and cell phone usage patterns among young adults with intellectual disabilities," Journal of Applied Research in Intellectual Disabilities 31(2018): 259-72.

${ }^{10}$ Jacek Pyżalski, Mariusz Przybyła i Michał Klichowski, ,Szanse i zagrożenia w obszarze wykorzystania technologii informacyjno-komunikacyjnych (TIK), ze szczególnym uwzględnieniem aplikacji mobilnych (TIK-mobApp) przez dzieci w wieku 3-6 lat" (Poznań: Uniwersytet im. A. Mickiewicza w Poznaniu, Narodowe Centrum Badań i Rozwoju, 2014).

${ }^{11}$ TNS Polska S.A., ,Rodzice i dzieci wobec zagrożeń dzieci w Internecie” (Warszawa: Fundacja Orange, 2016).

12 TNS Polska S.A., „Bezpieczeństwo dzieci w internecie. Raport z badań jakościowych i ilościowych" (Warszawa: Fundacja Orange, Fundacja Dzieci Niczyje, 2013), https://docplayer. pl/2803613-Bezpieczenstwo-dzieci-w-internecie-raport-z-badan-jakosciowych-i-ilosciowych.html.

${ }^{13}$ Krzyżak-Szymańska, Kowalkowska i Szymański, Zagrożenia dzieci i młodzieży w sieci.
} 
mych i ósmych szkoły podstawowej oraz klasach pierwszych, drugich i trzecich branżowej szkoły I stopnia. Badania zrealizowano w placówkach edukacyjnych zlokalizowanych w województwie śląskim i opolskim. Próba badawcza była całościowa. Łącznie badaniem objęto wszystkich rodziców, którzy w czasie badań brali udział w wywiadówkach szkolnych (N=1301). Do końcowej analizy dopuszczono 1295 wypełnionych kwestionariuszy. Przed rozpoczęciem badań zwrócono się do Komisji Bioetycznej AWF w Katowicach o wyrażenie zgody na realizację projektu ${ }^{14}$.

Badania miały charakter ilościowy. Zostały zrealizowane za pomocą metody sondażu diagnostycznego i techniki ankiety. W ramach przedsięwzięcia opracowano autorski kwestionariusz ankiety skierowany do rodziców, który przed realizacją został oceniony przez eksperta z zakresu uzależnień behawioralnych. Badania właściwe poprzedzono pilotażem. W placówkach edukacyjnych, objętych projektem, przygotowano badaczy terenowych (wychowawców i nauczycieli szkół specjalnych), którzy zrealizowali badania wśród rodziców.

Podstawowym celem prezentowanej części badań było:

- opisanie wiedzy rodziców na temat aktywności cyfrowych ich dzieci,

- scharakteryzowanie działań rodziców podejmowanych w domu rodzinnym w zakresie korzystania przez dzieci z nowych technologii cyfrowych,

- ustalenie poziomu kompetencji rodziców w obszarze korzystania z nowych technologii cyfrowych,

- opisanie identyfikowanych przez rodziców zagrożeń online, z którymi spotkały się dzieci w sieci.

Ostatecznie analizami objęto wypowiedzi 1295 rodziców. Matki stanowiły $78 \%$ badanych, a ojcowie $22 \%$ respondentów. Połowa rodziców (52\% respondentów) wychowywało dzieci, które uczęszczały do szkoły podstawowej specjalnej, a $48 \%$ z nich - dzieci uczęszczające do branżowej szkoły I stopnia (specjalnej). Badani byli w wieku od 26 lat do 71 lat. Najczęściej posiadali wykształcenie zawodowe (47\% matek i $64 \%$ ojców). Analizując ich status zawodowy stwierdzono, że prawie połowa $\mathrm{z}$ nich jest nieaktywna zawodowo (49\% matek, $37 \%$ ojców).

\footnotetext{
${ }^{14}$ Prezentowane wyniki badań są elementem projektu badawczego „Charakterystyka zjawiska problemowego używania internetu oraz telefonu komórkowego przez młodzież uczącą się z niepełnosprawnością intelektualną w stopniu lekkim” realizowanego przez AWF w Katowicach i współfinasowanego ze środków Funduszu Rozwiązywania Problemów Hazardowych będących w dyspozycji Ministra Zdrowia - umowa nr 360/HE/2018 oraz 8/HEK/2019. Projekt ten mieścił się w ramach zadania 5.5. Narodowego Programu Zdrowia dotyczącego między innymi badań naukowych w zakresie uzależnień behawioralnych.
} 
Analizę statystyczną zebranych wyników przeprowadzono w oparciu o program statystyczny Statistica 13.3.

\section{PREZENTACJA WYNIKÓW BADAŃ WŁASNYCH}

\subsection{Inicjacja technologiczna dzieci w opinii ich rodziców}

Ważnym elementem w ocenie podejmowanych przez dzieci aktywności online jest czasookres ich rozpoczęcia i podejmowania samodzielnych działań w sieci. W opinii rodziców średni wiek inicjacji samodzielnego korzystania z gier komputerowych przypadał na jedenasty rok życia, w przypadku korzystania z telefonu komórkowego na 11 lat i pół roku, a w przypadku internetu na 12 lat. Warto zauważyć, że niektórzy rodzice samodzielne poznawanie świata technologicznego organizowali dziecku w wieku 2-3 lat a inni dopiero w wieku 19-21 lat.

Ponieważ badania obejmowały dzieci na dwóch poziomach edukacyjnych, tj. podstawowym i zawodowym sprawdzono, czy istnieją statystycznie istotne różnice w inicjacji technologicznej w obu grupach. Ustalono za pomocą analizy testem rangowym U Manna-Whitneya, że różnice między analizowanymi grupami dzieci w zakresie wieku inicjacji technologicznej są istotne statystycznie. Dzieci, uczące się na poziomie podstawowym, rozpoczynały samodzielne korzystanie z urządzeń cyfrowych o około rok wcześniej niż dzieci uczące się na poziomie zawodowym. Dodatkowo matki częściej niż ojcowie deklarowały późniejszy wiek inicjacji technologicznej swoich dzieci. Różnica ta jednak wynosiła tylko kilka miesięcy. W trakcie analiz zauważono także prawidłowość, że im wyższe wykształcenie rodziców - tym wiek samodzielnego korzystania $\mathrm{z}$ nowych technologii był wyższy. Także status zawodowy rodzica miał istotny wpływ na inicjację technologiczną dziecka. Rodzice pracujący wcześniej niż niepracujący zezwalali na samodzielne korzystanie z gier komputerowych, telefonu komórkowego (średnio o około 1 roku wcześniej). W przypadku dostępu dzieci do internetu takich różnic istotnych statystycznie ze względu na status zawodowy rodzica nie stwierdzono.

\subsection{Aktywności cyfrowe dzieci i rodziców}

Zmierzając do całościowego poznania sytuacji korzystania z nowych technologii cyfrowych przez dzieci niepełnosprawne intelektualnie $\mathrm{w}$ stopniu lekkim starano się spojrzeć na to zagadnienie $\mathrm{z}$ perspektywy rodzica. W pierwszej kolejności zapytano badanych opiekunów o ich własną aktyw- 
ność cyfrową. Ustalono, że $90 \%$ z nich korzysta codziennie z telefonu komórkowego, $54 \%$ - z różnych zasobów internetu, 31\% - odwiedza portale społecznościowe, $7 \%$ - gra w gry komputerowe i $6 \%$ - korzysta z aplikacji. Taki stan rzeczy pokazuje, że badani rodzice aktywnie korzystają z nowych technologii cyfrowych (telefonu komórkowego, internetu). Natomiast nieliczna grupa z nich gra w gry komputerowe czy korzysta z aplikacji (patrz rysunek 1).

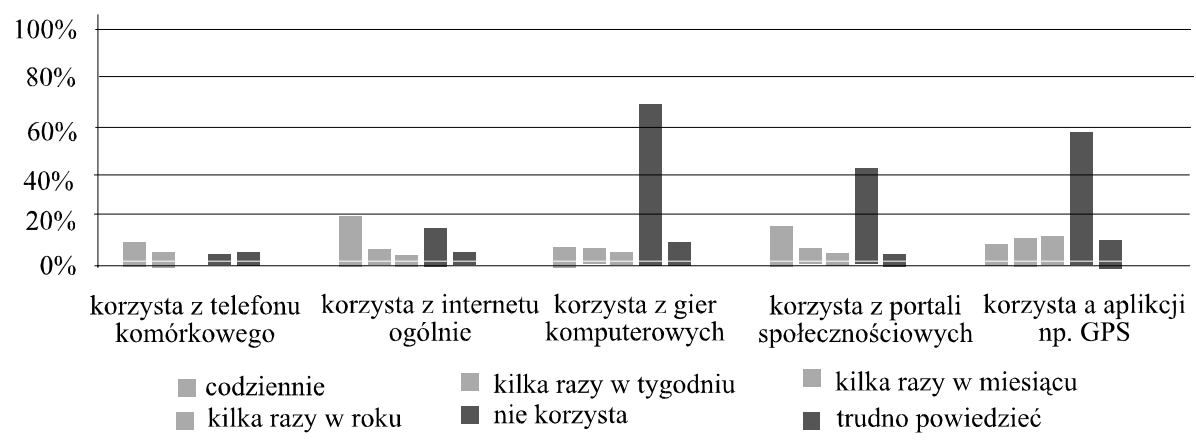

Rysunek 1. Korzystanie przez badanych rodziców z usług i urządzeń cyfrowych Źródło: badania własne

W badaniach poproszono również rodziców o wskazanie z jaką częstotliwością ich dzieci korzystają z tych samych usług i urządzeń cyfrowych. Ustalono, że dzieci (zdaniem rodziców) korzystają codziennie z telefonu komórkowego (tj. 83\%), internetu (67\%), portali społecznościowych (48\%). W mniejszym stopniu ich codzienną uwagę przyciągają gry (22\%) czy korzystanie z aplikacji (5\%). Szczegółowe dane w tym obszarze prezentuje rysunek 2.

W ramach badań stwierdzono występowanie statystycznie istotnego związku pomiędzy częstotliwością korzystania z usług i urządzeń cyfrowych przez rodzica a częstotliwością korzystania przez dziecko. W przypadku korzystania $\mathrm{z}$ telefonu komórkowego, używania internetu i grania w gry odnotowano dodatnie słabe korelacje. Natomiast, w zakresie korzystania z portali społecznościowych oraz aplikacji - ustalono dodatnie umiarkowane korelacje.

Z prowadzonych badań wynika, że $18 \%$ rodziców deklaruje, że dziecko korzysta $\mathrm{z}$ internetu tylko $\mathrm{w}$ domu. Pozostali wskazują na korzystanie przez dzieci z sieci także poza miejscem zamieszkania. Ta przestrzeń korzystania $\mathrm{z}$ technologii cyfrowych identyfikowana jest jako korzystanie w szkole (44\% wyborów), u znajomych lub rodziny (19\% wyborów), w miejscach publicznych z bezpłatnym Wi-Fi (15\% wyborów). Prawie połowa badanych rodziców 


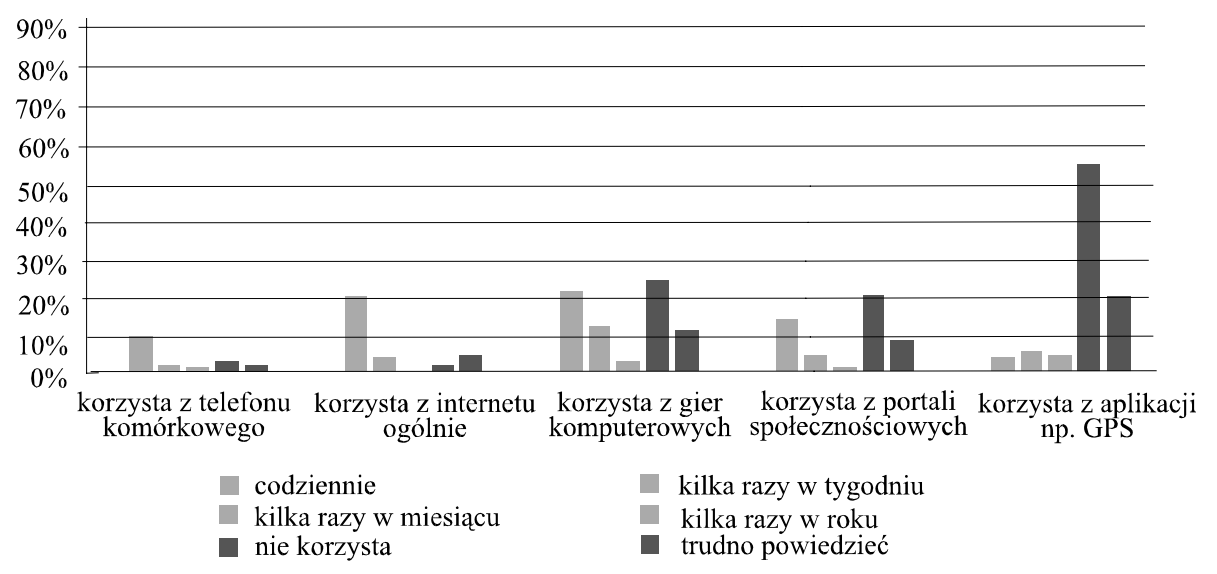

Rysunek 2. Korzystanie przez dzieci z usług i urządzeń cyfrowych Źródło: badania własne w opinii rodziców

(45\% respondentów) informuje o fakcie dysponowania przez dziecko telefonem komórkowym z nieograniczonym dostępem do internetu, co pozwala mu na korzystanie z sieci, kiedy i gdzie chce. Ustalono, że takie zmienne, jak: płeć, wykształcenie, wiek czy status zawodowy rodzica nie miały istotnego statystycznie wpływu na używanie przez dziecko internetu poza domem.

W trakcie badań zapytano również rodziców o ich wiedzę na temat korzystania przez dzieci z portali społecznościowych. Co piąty rodzic ( $21 \%$ badanych) wskazuje na brak konta dziecka na jakimkolwiek portalu społecznościowym, co drugi z nich wie o użytkowaniu przez dziecko przynajmniej jednego portalu społecznościowego (66\% respondentów), a co ósmy (13\% badanych) informuje, że nie posiada takiej wiedzy. Co ciekawe, $31 \%$ rodziców deklarowało w badaniu, że posiada konto na portalu społecznościowym i wszyscy oni mieli również wiedzę o korzystaniu przez ich dziecko z mediów społecznościowych. Wśród najczęściej wskazywanych mediów społecznościowych rodzice wymieniali Facebook (91\% wyborów) i Instagram (7\% wyborów). Na podstawie przeprowadzonej analizy stwierdzono:

- brak istotnych statystycznie różnic (ze względu na płeć i wiek) w posiadanej wiedzy przez rodzica na temat korzystania przez dziecko z portali społecznościowych;

- występowanie istotnych statystycznie zależności pomiędzy wykształceniem i statusem zawodowym rodzica a jego wiedzą na temat korzystania przez dziecko z portali społecznościowych. Ustalono, że rodzice z wykształceniem wyższym częściej od pozostałych wskazywali na brak posiadania przez 
dziecko konta na portalu społecznościowym. Dodatkowo stwierdzono, że rodzice pracujący częściej mieli wiedzę na temat posiadania przez dziecko konta na profilu społecznościowym niż ci, którzy nie pracowali.

Ważnym zagadnieniem było także określenie przez rodziców ich kompetencji technologicznych i zestawienie ich z kompetencjami ich dzieci. Badani określili swoje kompetencje na skali ocen szkolnych od 2 do 6 , gdzie 2 oznaczało niedostateczną ocenę swoich kompetencji, a 6 ocenę celującą. $\mathrm{Z}$ przeprowadzonych analiz wynika, że średnia ocena kompetencji cyfrowych badanych rodziców wynosiła 3,8 . W przypadku rodziców pracujących osiągała wartość 3,9, a w przypadku rodziców niepracujących 3,6. Dodatkowo rodzice poniżej czterdziestego roku życia oceniali swoje kompetencje na poziomie 4,3 , a powyżej czterdziestu lat - na poziomie 3,6.

Badani rodzice, określając poziom kompetencji swoich dzieci, wskazali na średnią ocenę 5,2, przy czym najniższy wskazany wynik wynosił 3,0 a najwyższy 6,0. Dodatkowo ustalono, że $80 \%$ badanych rodziców deklarowało posiadanie niższych kompetencji cyfrowych od swoich dzieci. Taki obraz przełożył się częściowo na deklarowaną przez rodziców pomoc dziecku w sytuacji wystąpienia zagrożenia online. Bowiem stwierdzono istotny statystycznie związek pomiędzy deklarowanymi kompetencjami technologicznymi rodzica a kompetencjami rodzica do pomocy dziecku w sytuacji zagrożenia online. Czym niższe kompetencje cyfrowe miał rodzic, tym rzadziej deklarował swoje kompetencje pomocy w zakresie cyber-zagrożeń.

\subsection{Zasady korzystania $\mathrm{z}$ technologii cyfrowych wprowadzone} w domu rodzinnym

W ramach badań zapytano rodziców o obowiązujące w ich domu zasady korzystania z komputera i internetu oraz telefonu komórkowego.

Jak wynika z zebranych danych $72 \%$ badanych rodziców deklarowało stosowanie w domu zasad korzystania przez dziecko z komputera i internetu. Najczęściej wymieniali oni zakaz używania komputera i internetu w nocy (48\% wyborów respondentów), korzystania z urządzenia podczas wyznaczonej przez rodzica kary (45\% wyborów respondentów) lub w sytuacji, gdy dziecko nie skończyło odrabiać lekcji (31\% wyborów respondentów) czy zakaz pobierania $\mathrm{z}$ internetu gier, filmów lub muzyki (31\% wyborów respondentów). Szczegółowe dane w tym obszarze przedstawia tabela 1 . 
Tabela 1. Obowiązujące dzieci w domu rodzinnym zasady dotyczące korzystania $\mathrm{z}$ komputera i internetu $\mathrm{w}$ deklaracjach rodziców

\begin{tabular}{|l|c|c|}
\hline \multicolumn{1}{|c|}{ Rodzaj zasady } & \multicolumn{2}{c|}{ Ogółem } \\
& \multicolumn{1}{|c|}{$\mathrm{N}=1295$} \\
\cline { 2 - 3 } & $\mathrm{N}$ & $\%$ \\
\hline Dziecko nie może korzystać z komputera lub internetu, gdy ma karę & 586 & 45 \\
\hline Dziecko nie może korzystać z FB, gdy ma karę & 355 & 27 \\
\hline Dziecko nie może grać w gry, gdy ma karę & 397 & 31 \\
\hline Dziecko nie może korzystać z komputera lub internetu w nocy & 618 & 48 \\
\hline $\begin{array}{l}\text { Dziecko może korzystać z komputera lub internetu, gdy wykona obo- } \\
\text { wiązki domowe }\end{array}$ & 405 & 31 \\
\hline Dziecko może korzystać z komputera lub internetu, gdy odrobi lekcje & 438 & 34 \\
\hline Dziecko może grać w gry komputerowe, gdy wykona obowiązki domowe & 299 & 23 \\
\hline Dziecko może grać w gry komputerowe, gdy odrobi lekcje & 297 & 23 \\
\hline Dziecko nie może grać w gry komputerowe dla dorosłych & 382 & 29 \\
\hline $\begin{array}{l}\text { Dziecko nie może używać kamerki internetowej, gdy rozmawia przez } \\
\text { internet }\end{array}$ & 159 & 12 \\
\hline $\begin{array}{l}\text { Dziecko nie może ściągać z internetu gier, muzyki, filmów, które są } \\
\text { płatne }\end{array}$ & 445 & 34 \\
\hline Wprowadziłem/wprowadziłam własne zasady & 65 & 5 \\
\hline
\end{tabular}

Źródło: badania własne

Jak wynika z przeprowadzonych analiz zmienna płci oraz statusu zawodowego rodzica nie różnicowała istotnie statystycznie zasad korzystania przez dziecko z komputera i internetu. Natomiast zmienna wykształcenia istotnie statystycznie różnicowała wszystkie wymienione przez rodziców zasady, w taki sposób, że im wyższe wykształcenie rodziców, tym częściej wprowadzali oni zasady korzystania przez dziecko z komputera i internetu.

W przypadku zmiennej wieku zauważono jej istotny związek z wprowadzaniem w domu przez rodziców zasad dotyczących zakazu korzystania z komputera czy internetu wtedy gdy dotyczy tego kara, zakazu korzystania $\mathrm{z}$ urządzeń $\mathrm{w}$ nocy, grania w gry dla dorosłych, czy korzystania z kamerki internetowej podczas prowadzenia komunikacji przez internet. We wszystkich wymienionych przypadkach rodzice w wieku do 35 roku życia częściej niż rodzice powyżej 35 roku życia stosowali wymienione zasady wobec swoich dzieci.

Natomiast w zakresie wyznaczania przez rodziców zasad korzystania przez dziecko z telefonu komórkowego w domu rodzinnym ustalono, że $2 / 3$ bada- 
nych rodziców (tj. 70\% respondentów) wprowadziło takie zasady. Do najczęściej ustalanych zasad - w opinii badanych opiekunów - należały te dotyczące zakazu korzystania $\mathrm{z}$ telefonu w nocy (45\% wyborów respondentów), wtedy, gdy rodzic wyznaczył taką karę (41\% wyborów respondentów) lub zakazu korzystania z telefonu podczas posiłku (39\% wyborów respondentów). Szczegółowe dane w tym zakresie prezentuje rysunek 3.

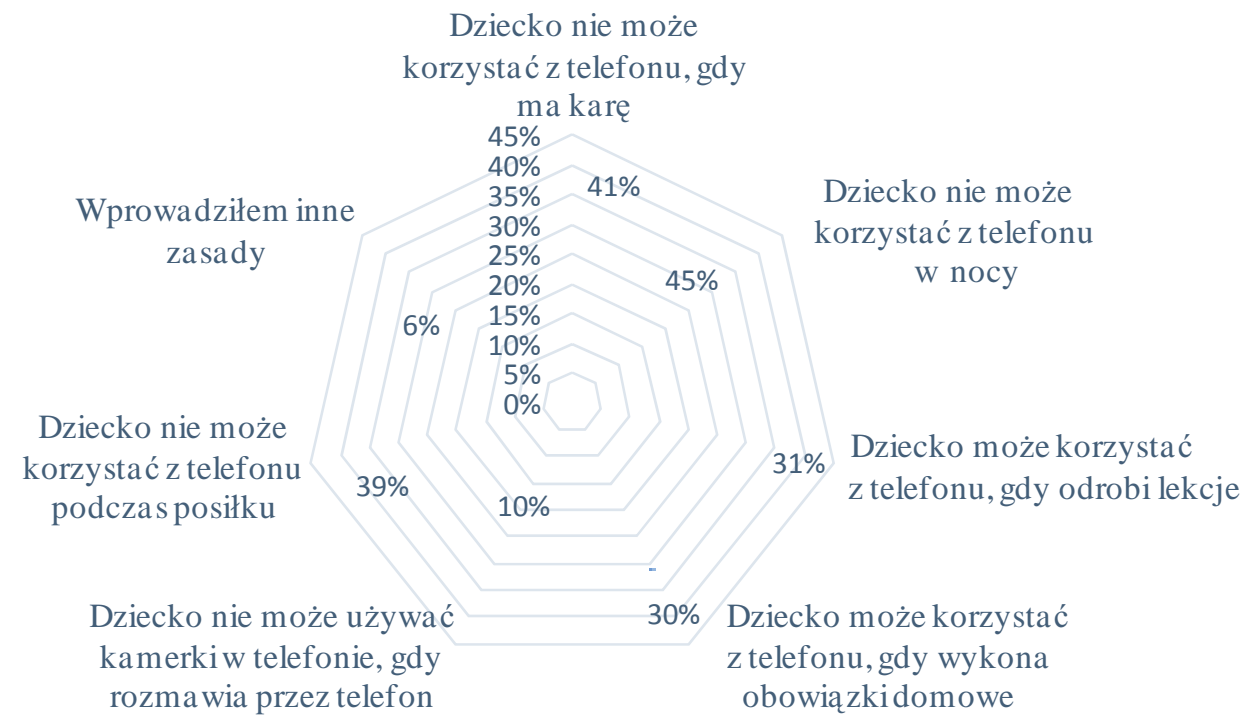

Rysunek 3. Zasady dotyczące używania telefonu komórkowego przez dziecko obowiązujące $\mathrm{w}$ domu rodzinnym $\mathrm{w}$ opinii rodziców

Źródło: badania własne

Ustalono, że płeć rodzica istotnie statystycznie różnicowała wprowadzane przez rodziców zasady w zakresie zakazu używania kamerki podczas prowadzenia rozmowy przez telefon. To ojcowie częściej od matek wskazywali na tę zasadę. Z kolei wykształcenie rodzica różnicowało wszystkie wymienione w pytaniu zasady korzystania $\mathrm{z}$ telefonu komórkowego z wyjątkiem zasady dotyczącej korzystania z kamerki internetowej podczas rozmowy, w taki sposób, że im wyższe wykształcenie rodzica tym częściej rodzic wprowadzał w domu rodzinnym omawiane zasady. Natomiast zmienna wieku miała istotny statystycznie związek z wyznaczaniem następujących zasad: 
- zakazu korzystania z telefonu komórkowego podczas kary wyznaczonej przez rodzica (rodzice $w$ wieku 30-40 lat, 56-60 lat oraz powyżej 66 lat częściej od pozostałych stosowali tę zasadę);

- zakazu korzystania z telefonu w nocy (rodzice w wieku 30-40 lat, 56-60 lat oraz powyżej 66 lat częściej od pozostałych stosowali tę zasadę);

- zakazu korzystania z telefonu, gdy dziecko ma nieodrobione lekcje (rodzice w wieku 30-40 lat oraz 56-60 lat częściej od pozostałych stosowali tę zasadę);

- zakazu korzystania z telefonu podczas posiłku (rodzice w wieku 30-40 lat oraz 56-60 lat częściej od pozostałych stosowali tę zasadę).

Na uwagę zasługuje również fakt, że część rodziców deklarowała brak jakichkolwiek zasad w obszarze używania komputera i internetu (28\%) czy telefonu komórkowego (30\% rodziców) przez dziecko. Zmienna statusu zawodowego w istotny sposób różnicowała brak zasad domowych dotyczących korzystania z internetu czy telefonu komórkowego. To rodzice pracujący rzadziej niż rodzice niepracujący deklarowali brak jakichkolwiek zasad w przedmiotowym zakresie. Natomiast takie zmienne, jak: płeć, wykształcenie i wiek rodzica nie różnicowały istotnie statystycznie braku wprowadzenia jakichkolwiek zasad dotyczących korzystania $\mathrm{z}$ technologii cyfrowych przez rodziców.

2.4. Cyber-zagrożenia z jakimi bezpośrednio spotkało się dziecko w opinii rodziców

Pytając rodziców o aktywność online ich dzieci zwrócono także uwagę na ich wiedzę na temat doświadczeń potomstwa w sieci w zakresie zagrożeń online. Ponad połowa $\mathrm{z}$ nich (58\% badanych) nie stwierdziła w okresie 12 miesięcy przed badaniem wymienionych $\mathrm{w}$ pytaniu sytuacji. Pozostali identyfikowali:

- nadużywanie internetu (30\% respondentów);

- znajdowanie w sieci materiałów, które były nieadekwatne dla ich wieku (10\% respondentów);

- pobranie aplikacji lub programu, który wymagał opłaty przez rodzica (5\% respondentów);

- bycie przedmiotem wyśmiewania ze względu na to, co dziecko opublikowało w sieci (4\% respondentów);

- namawianie dziecka do jakiegoś złego zachowania (4\% respondentów);

- spotkanie dziecka z osobą poznaną w sieci (4\% respondentów).

Sprawdzono, czy takie zmienne, jak: wiek, płeć, wykształcenie czy status zawodowy rodzica różnicowały w istotny statystycznie sposób wiedzę rodzi- 
ców na temat zagrożeń online, z którymi spotkało się ich dziecko. Ustalono, że płeć rodzica nie miała statystycznie istotnego związku $\mathrm{z}$ wiedzą rodziców na temat zagrożeń online, których doświadczyły ich dzieci. Natomiast wiek opiekuna różnicował $\mathrm{w}$ istotny statystycznie sposób wiedzę rodzica w zakresie spotkania się dziecka w sieci z materiałami, które były niewłaściwe dla wieku dziecka (im wyższy wiek rodzica, tym posiadał on mniejszą wiedzę o wystąpieniu przedmiotowego zagrożenia u dziecka). Także zmienna wykształcenia istotnie statystycznie różnicowała wiedzę rodzica o wystąpieniu cyber-zagrożeń podczas korzystania przez dziecko z sieci. Stwierdzono, że im rodzice mieli wyższe wykształcenie, tym częściowej wiedzieli oni o:

- nadużywaniu przez dziecko internetu, tj. dostrzegali w zachowaniu dziecka symptomy nałogowości zachowania;

- znajdowaniu w sieci materiałów nieadekwatnych dla wieku dziecka;

- sytuacjach wyśmiewania dziecka w sieci.

Podczas analiz ujawniono również istotne statystycznie różnice ze względu na status zawodowy rodzica (pracuje-nie pracuje) w zakresie wiedzy o cyberzagrożeniach, jakich doświadczyło dziecko. Ustalono, że rodzice pracujący istotnie częściej niż rodzice nie pracujący informowali o nałogowym korzystaniu przez dziecko z internetu oraz o natrafianiu przez dziecko w sieci na nieadekwatne do wieku materiały.

Dodatkowo, biorąc pod uwagę fakt udziału w badaniach rodziców dzieci uczących się na poziomie podstawowym i zawodowym, starano się sprawdzić czy wiek dziecka ma istotny statystycznie związek z wiedzą rodziców na temat doświadczanych przez niego cyber-zagrożeń. Ustalono, że jest on istotny w przypadku jednego z zagrożeń, tj. spotykania przez dziecko w sieci materiałów niewłaściwych ze względu na jego wiek - w taki sposób, że rodzice dzieci uczących się w szkole podstawowej (12\% respondentów) częściej niż opiekunowie dzieci starszych, uczących się w szkole zawodowej (7\% respondentów) wiedzieli o wystąpieniu przedmiotowego zagrożenia.

\section{PODSUMOWANIE}

Rodzice, stając się kreatorami środowiska rodzinnego oraz drogowskazami procesu socjalizacji, są także uczestnikami świata mediów swoich dzieci. Sytuacja taka dotyczy w szczególności rodziców dzieci niepełnosprawnych intelektualnie w stopniu lekkim, którym należy się wzmożona uwaga i pomoc w korzystaniu z nowych technologii cyfrowych. 
Przeprowadzone badania pokazują, że dzieci niepełnosprawne, tak jak i pełnosprawni rówieśnicy aktywnie uczestniczą w życiu online, a ich rodzice starają się im pomagać w tych aktywnościach. Mimo że część opiekunów nie posiada wystarczających kompetencji technologicznych, aby być pełnoprawnym partnerem swojego dziecka w cyfrowym świecie, to starają się oni stworzyć im warunki bezpiecznego przebywania w tym techno-systemie.

Na podstawie przeprowadzonych badań sformułowano następujące wnioski:

1. Rodzice deklarowali rozpoczęcie samodzielnego korzystania z nowych technologii cyfrowych przez swoje dzieci od korzystania z gier komputerowych (średni wiek inicjacji to 11 lat). Następnie pozwalali oni dziecku na samodzielne korzystanie z telefonu komórkowego (średni wiek inicjacji to 11 i pół roku), a dopiero w wieku 12 lat umożliwiali dzieciom samodzielną przygodę $\mathrm{z}$ internetem.

2. W większości badani rodzice korzystali z nowych technologii cyfrowych. Częstotliwość ich używania miała istotny statystycznie związek z częstotliwością korzystania z nowych mediów przez ich dzieci. Zauważono, że im rodzice częściej korzystają z nowych mediów, tym ich dzieci robią to także częściej.

3 . Ponad $2 / 3$ rodziców deklarowało wprowadzenie w domu rodzinnym zasad dotyczących korzystania z nowych technologii cyfrowych. Pozostali informowali o braku jakichkolwiek zasad obowiązujących w domu a dotyczących korzystania z komputera, internetu czy telefonu komórkowego przez dziecko. Zmienną, która w istotny sposób różnicowała ten stan, był status zawodowy rodzica w taki sposób, że rodzice pracujący rzadziej niż niepracujący deklarowali brak jakichkolwiek zasad w omawianym zakresie.

4. Badani opiekunowie identyfikowali szereg zagrożeń, z którymi spotykały się ich dzieci online. Prawie co trzeci z nich zgłaszał nadużywanie internetu przez dziecko, co dziesiąty rodzic wskazywał na kontakt dziecka w sieci z materiałami nieadekwatnymi do jego wieku, a co dwudziesty informował o potrzebie uregulowania płatności za ściągnięte przez dziecko z sieci aplikacje lub programy.

\section{BIBLIOGRAFIA}

Caton, Sue, and Melanie Chapman. „The use of social media and people with intellectual disability: A systematic review and thematic analysis". Journal of Intellectual and Developmental Disability 41(2016): 125-39.

Gałecki, Piotr, Maciej Pilecki, Joanna Rymaszewska, Agata Szulc, Sławomir Sidorowicz i Jacek Wciórka. Kryteria diagnostyczne zaburzeń psychicznych DSM-5. Wydanie piąte. Wrocław: EDRA Urban i Partner, 2018. 
Jenaro, Cristina, Noelia Flores, Maribel Cruz, Ma Carmen Pérez, Vanessa Vega, and Victor Torres. „Internet and cell phone usage patterns among young adults with intellectual disabilities." Journal of Applied Research in Intellectual Disabilities 31(2018): 259-72.

Johnson, Genevieve Marie, and Korbla Puplumpu. „Internet Use during Childhood and the Ecological Techno-Subsystem." Canadian Journal of Learning and Technology 34(2008), https://doi.org/10.21432/T2CP4T.

Krzyżak-Szymańska, Ewa, Joanna Kowalkowska i Andrzej Szymański. Zagrożenia dzieci i mtodziezy $w$ sieci: cyberproblemy, diagnoza i profilaktyka: vademecum nauczyciela. Katowice: GWSH w Katowicach, 2016.

Normand, Claude L., and François Sallafranque-St-Louis. „Cybervictimization of Young People With an Intellectual or Developmental Disability: Risks Specific to Sexual Solicitation." Journal of Applied Research in Intellectual Disabilities 29(2016): 99-110.

Plichta, Piotr. Socjalizacja $i$ wychowanie dzieci i młodzieży z niepetnosprawnościa intelektualna w erze cyfrowej. Torun: Wydawnictwo Adam Marszałek, 2017.

Pyżalski, Jacek, Mariusz Przybyła i Michał Klichowski. Szanse i zagrożenia w obszarze wykorzystania technologii informacyjno-komunikacyjnych (TIK), ze szczególnym uwzględnieniem aplikacji mobilnych (TIK-mobApp) przez dzieci w wieku 3-6 lat. Poznań: Uniwersytet im. A. Mickiewicza w Poznaniu, Narodowe Centrum Badań i Rozwoju, 2014.

Pyżalski, Jacek, Aldona Zdrodowska, Łukasz Tomczyk i Katarzyna Abramczuk. Polskie badanie EU Kids Online 2018. Najważniejsze wyniki i wnioski. Poznań: Wydawnictwo Naukowe UAM, 2019.

Schalock, Robert L., Ruth Luckasson, and Marc J. Tassé. „Intellectual Disability: Definition, Diagnosis, Classification, and Systems of Supports, 12th Edition". AAIDD, 2021, https:// www. aaidd.org/publications/bookstore-home/product-listing/intellectual-disabil ity-definition-diagnosis-classification-and-systems-of-supports-12th-edition.

Szymański, Andrzej i Ewa Krzyżak-Szymańska. „Rola rodziców w zapobieganiu nadużywania przez dzieci nowych technologii cyfrowych", Serwis Informacyjny UZALEŻNIENIA, 3(2018): 17-21.

TNS Polska S.A. Bezpieczeństwo dzieci w internecie. Raport z badań jakościowych i ilościowych. Warszawa: Fundacja Orange, Fundacja Dzieci Niczyje, 2013, https://docpl ayer. pl/2803613-Bezpieczenstwo-dzieci-w-internecie-raport-z-badan-jakosciowych-i-ilosciowych. html.

TNS Polska S.A. Rodzice i dzieci wobec zagrożeń dzieci w Internecie. Warszawa: Fundacja Orange, 2016.

\title{
KORZYSTANIE Z NOWYCH TECHNOLOGII CYFROWYCH PRZEZ DZIECI NIEPEŁNOSPRAWNE INTELEKTUALNIE W OPINII RODZICÓW
}

\author{
St r e s z c z e n i e
}

Artykuł przedstawia wyniki badań prowadzonych wśród rodziców dzieci niepełnosprawnych intelektualnie w stopniu lekkim. Ich celem było opisanie wiedzy rodziców na temat aktywności cyfrowych ich dzieci oraz scharakteryzowanie działań opiekunów w zakresie korzystania przez dzieci z nowych technologii cyfrowych. Badania zrealizowano metodą sondażu diagnostycznego. Objęto nimi 1295 osób. W badaniach stwierdzono statystycznie istotne związki pomiędzy 
częstotliwością korzystania z nowych mediów przez rodziców a częstotliwością korzystania $\mathrm{z}$ nich przez dzieci. Ustalono, że rodzice w pierwszej kolejności pozwalali dzieciom na samodzielne korzystanie z gier komputerowych (średni wiek inicjacji używania wynosił 11 lat), później z telefonu komórkowego (średni wiek inicjacji używania wynosił 11 lat i pół roku). Następnie wprowadzali dziecko w świat online (średni wiek inicjacji wynosił 12 lat). Dodatkowo stwierdzono istotne statystycznie różnice pomiędzy rodzicami pracującymi a niepracującymi w zakresie stosowanych w domu zasad korzystania z nowych mediów. Prawie 1/3 respondentów zgłaszała nadużywanie internetu przez dziecko, co dziesiąty rodzic wskazywał na kontakt dziecka w sieci z materiałami nieadekwatnymi do jego wieku, a co dwudziesty opiekun informował o potrzebie uregulowania płatności za ściągnięte przez dziecko z sieci aplikacje lub programy.

Słowa kluczowe: dzieci z niepełnosprawnością intelektualną; inicjacja technologiczna; zagrożenia w sieci; rodzice. 